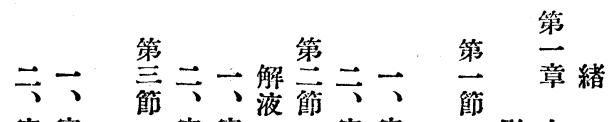

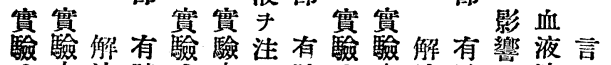

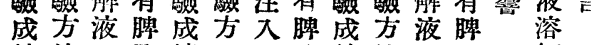
績法皮綪法七及績法皮及解

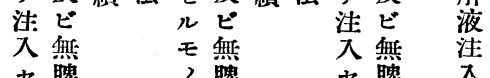

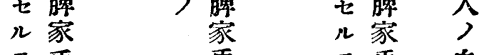
モ兔鬼鬼

, $=$ 異向

種種

血

溶

同
種
液
溶

鬼

自 液

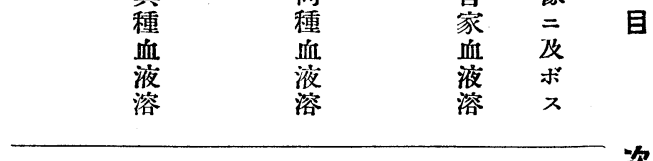

第第 第
第第
節
節 總卜脾驗驗 赤剔戍方

論血出績法レ素績法響成捪

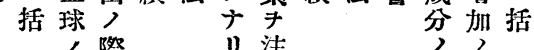

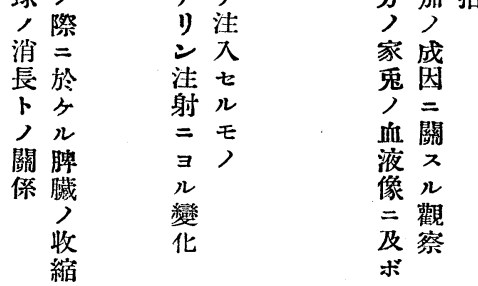

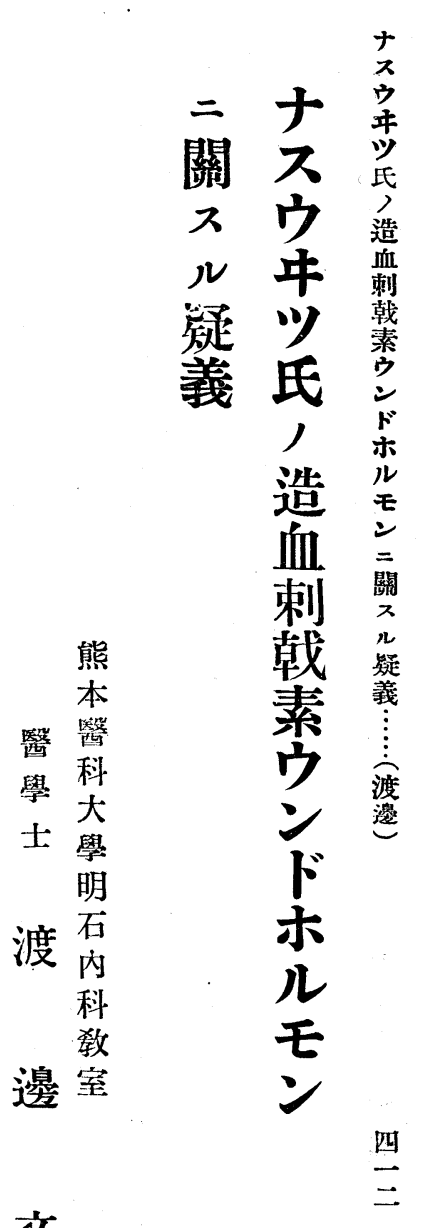

交

雄 


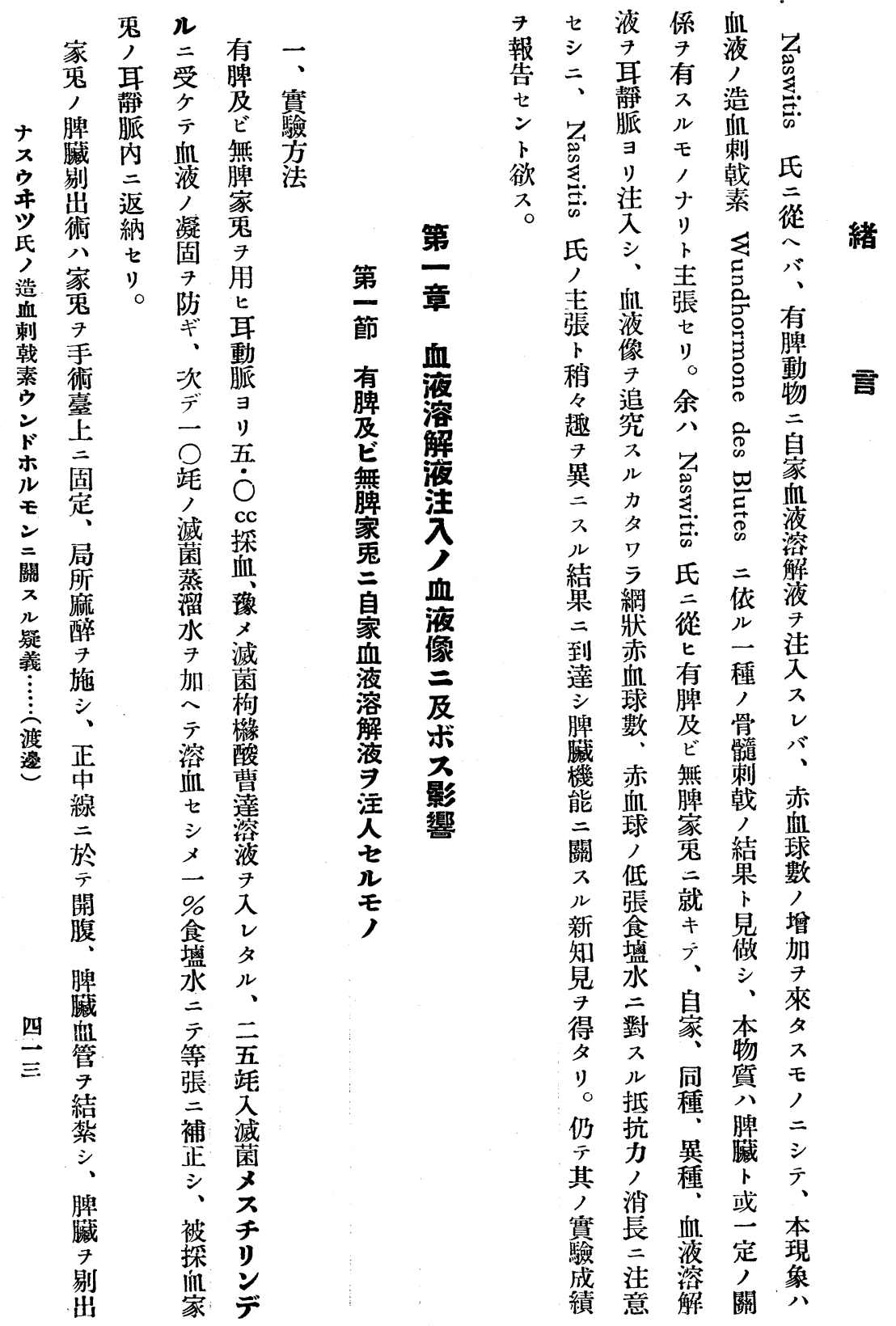


第一表ノ一

\begin{tabular}{|c|c|c|c|c|c|c|c|c|c|c|}
\hline \multirow{3}{*}{ 日 } & \multirow{3}{*}{ 時 } & \multirow{3}{*}{$\begin{array}{l}\text { 白 } \\
\text { 血 } \\
\text { 球 }\end{array}$} & \multirow{3}{*}{$\begin{array}{l}\text { 赤 } \\
\text { 血 } \\
\text { 球 }\end{array}$} & \multirow{3}{*}{$\begin{array}{l}\text { 血 } \\
\text { 色 } \\
\text { 素 }\end{array}$} & \multirow{3}{*}{$\begin{array}{l}\text { 色 } \\
\text { 素 } \\
\text { 係 } \\
\text { 數 }\end{array}$} & \multirow{2}{*}{\multicolumn{2}{|c|}{ 赤血球抵抗 }} & \multirow{2}{*}{\multicolumn{3}{|c|}{$\frac{\text { 同容積內=於々ル }}{\text { 赤血球 網狀赤血球數 }}$}} \\
\hline & & & & & & & & & & \\
\hline & & & & & & 最大 & 最小 & 數 & 數 & $\%$ \\
\hline \multicolumn{11}{|c|}{ No. I \& 2000 瓦 有脾家鬼 =自家血液溶解液キ注入セルモ) (1 月 14 日一 18 日) } \\
\hline \multicolumn{2}{|c|}{ 注射前 } & 11800 & 528萬 & 105 & 2.0 & 0.56 & 0.40 & 738 & 4 & 0.5 \\
\hline \multicolumn{11}{|c|}{ 血液 5.0 䇇き探血, 溶血セシメテ注入ス } \\
\hline \multirow[t]{4}{*}{ 注射後 } & 2 日 & 1600 & 573 & 106 & 1.8 & 0.60 & 0.44 & 565 & 7 & 1.2 \\
\hline & 8日 & 15500 & 440 & 97 & 2.2 & 0.58 & $0: 38$ & 683 & 23 & 3.3 \\
\hline & 4 日 & 6800 & 512 & 103 & 2.0 & 0.56 & 0.38 & 697 & 31 & 4.4 \\
\hline & 5 日 & 7100 & 539 & 105 & 1.9 & 0.56 & 0.40 & 739 & 32 & 4.3 \\
\hline \multicolumn{11}{|c|}{ No. II 守 2160 瓦 } \\
\hline \multirow{2}{*}{ 注射前 } & \multirow{2}{*}{\multicolumn{10}{|c|}{ 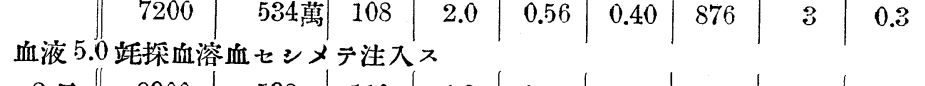 }} \\
\hline & & & & & & & & & & \\
\hline \multirow[t]{4}{*}{ 注射後 } & 2 日 & 8900 & 598 & 110 & 1.8 & 0.58 & 0.42 & 838 & 11 & 1.3 \\
\hline & 3 日 & 5900 & 498 & 100 & 2.0 & 0.58 & 0.42 & 726 & 9 & 1.2 \\
\hline & 4 日 & 7200 & 574 & 109 & 1.8 & 0.58 & 0.42 & 937 & 21 & 2.2 \\
\hline & 5 日 & 6800 & 570 & 109 & 1.9 & 0.58 & 0.40 & 901 & 23 & 2.5 \\
\hline \multicolumn{11}{|c|}{ No. III \& 2200 瓦 有脾家鬼二自家血液溶解液キ注入セルモノ( 2 月 14 日一 29 日) } \\
\hline \multicolumn{2}{|c|}{ 注射前 } & 7400 & 519 萬 & 98 & 1.6 & 0.60 & 0.42 & 756 & 11 & 1.4 \\
\hline \multicolumn{11}{|c|}{ 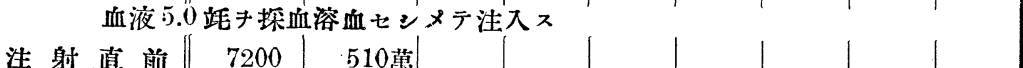 } \\
\hline 注 射 & 㨁 前 & 7200 & 510 萬 & & & & & & & \\
\hline $\begin{array}{r}\text { 注射後 } 1 \\
2\end{array}$ & $\begin{array}{l}1 \text { 時間 } \\
2 \text { 時間 }\end{array}$ & 18500 & $\begin{array}{l}683 \\
674\end{array}$ & & & & & 838 & 10 & 1.1 \\
\hline & 3 時間 & & 646 & & & & & & & \\
\hline & 2 日 & 15900 & 577 & 100 & 1.7 & 0.62 & 0.46 & 733 & 12 & 1.6 \\
\hline & 4 時間 & & 433 & & & & & & & \\
\hline & 3 日 & 14800 & 489 & 92 & 1.9 & 0.60 & 0.42 & 546 & 11 & 2.0 \\
\hline & 4 日 & 11700 & 528 & 103 & 1.9 & 0.60 & 0.42 & 463 & 13 & 2.8 \\
\hline & 5 日 & 9600 & 524 & 100 & 1.9 & 0.56 & 0.40 & 733 & 27 & 3.8 \\
\hline & 6 日 & 6900 & 516 & 100 & 1.9 & 0.54 & 0.40 & 648 & 42 & 6.1 \\
\hline & 8 日 & 7200 & 538 & 101 & 1.8 & 0.56 & 0.38 & 714 & 31 & 4.8 \\
\hline & 10 日 & 7700 & 542 & 103 & 1.9 & 0.56 & 0.40 & 725 & 24 & 3.3 \\
\hline & 12 日 & 6300 & 567 & 101 & 1.9 & 0.58 & 0.42 & 745 & 12 & 1.5 \\
\hline & 15 日 & 5700 & 585 & 108 & 1.9 & 0.56 & 0.38 & 849 & 12 & 1.4 \\
\hline
\end{tabular}




\begin{tabular}{|c|c|c|c|c|c|c|c|c|c|}
\hline \multirow{3}{*}{ 日 } & \multirow{3}{*}{$\begin{array}{l}\text { 白 } \\
\text { 血 } \\
\text { 球 }\end{array}$} & \multirow{3}{*}{$\begin{array}{l}\text { 赤 } \\
\text { 血 } \\
\text { 球 }\end{array}$} & \multirow{3}{*}{$\begin{array}{l}\text { 血 } \\
\text { 色 } \\
\text { 素 }\end{array}$} & \multirow{3}{*}{$\begin{array}{l}\text { 色 } \\
\text { 素 } \\
\text { 㛊 } \\
\text { 數 }\end{array}$} & \multicolumn{2}{|c|}{ 赤血球抵抗 } & \multicolumn{3}{|c|}{ 同容樍内 = 於々ル } \\
\hline & & & & & & & 赤血球 & \multicolumn{2}{|c|}{ 網狀赤血球數 } \\
\hline & & & & & 最大 & 最小 & 数 & 數 & $\%$ \\
\hline \multicolumn{10}{|c|}{ No. IV \& 2600 瓦 有脾家鬼二自家血液溶解液キ注入七nモ> } \\
\hline 注射前 & 6900 & 536萬 & 102 & 1.9 & 0.60 & 0.40 & 817 & 14 & 1.7 \\
\hline \multicolumn{10}{|c|}{ 血液 5.0 距き啋血溶血セシメテ注入ス } \\
\hline 直 前 & 7100 & 531 落 & & & & & & & \\
\hline 注射後 1 跱間 & 11700 & 699 & & & & & & & \\
\hline 2 時間 & 673 & & & & & & 898 & 13 & 1.4 \\
\hline 3 時間 & 654 & & & & & & 836 & 11 & 1.3 \\
\hline 2 日 & 1740 & 640 & 104 & 1.6 & 0.62 & 0.44 & 737 & 13 & 1.7 \\
\hline 24 時間 & & & 449 & & & & & & \\
\hline 3 日 & 10700 & 542 & 100 & 1.8 & 0.58 & 0.40 & 699 & 13 & 1.8 \\
\hline 4 日 & 10300 & 559 & 100 & 1.7 & 0.56 & 0.40 & 857 & 17 & 1.9 \\
\hline 5 日 & 9400 & 539 & 106 & 1.9 & 0.54 & 0.40 & 795 & 18 & 2.2 \\
\hline 6 日 & 7900 & 568 & 108 & 1.9 & 0.54 & 0.42 & 740 & 13 & 1.7 \\
\hline 8 日 & 7200 & 548 & 108 & 1.9 & 0.56 & 0.40 & 750 & 22 & 2.9 \\
\hline 10 日 & 6800 & 552 & 105 & 1.9 & 0.56 & 0.42 & 751 & 21 & 2.7 \\
\hline 13 日 & 833 & 531 & 105 & 1.9 & 0.58 & 0.40 & 769 & 12 & 1.5 \\
\hline 15 日 & 8400 & 541 & 102 & 1.9 & 0.56 & 0.42 & 763 & 8 & 1.0 \\
\hline
\end{tabular}

第一表ノニ

\begin{tabular}{|c|c|c|c|c|c|c|c|c|c|c|c|c|c|}
\hline \multirow{2}{*}{$\begin{array}{l}\text { 月 } \\
\text { 日 }\end{array}$} & \multicolumn{2}{|r|}{ 白 } & 血 & \multicolumn{2}{|c|}{ 百 } & \multicolumn{2}{|c|}{ 率 } & \multirow{2}{*}{ - } & \multirow{2}{*}{\multicolumn{2}{|c|}{ 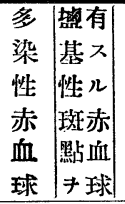 }} & \multirow{2}{*}{\begin{tabular}{l|} 
渏 \\
形 \\
赤 \\
血 \\
球
\end{tabular}} & \multirow{2}{*}{\multicolumn{2}{|c|}{ 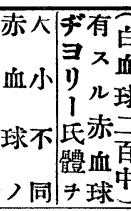 }} \\
\hline & M.E & P.E & $\mathrm{L}$ & $\mathrm{E}$ & B & M & Pl. & & & & & & \\
\hline \multicolumn{14}{|c|}{ 自家血液溶解液注入（有脾家鬼） } \\
\hline $14 / I$ & 1 & 66.0 & 28.0 & 1.0 & 1 & 5.0 & 1 & 1 & + & 1 & 1 & + & 1 \\
\hline $15 / I$ & 1 & 86.0 & 9.0 & 1 & 1 & 5.0 & 1. & 1 & + & 1 & 1 & + & 1 \\
\hline $16 / I$ & 1 & 54.5 & 41.5 & 0.5 & 1 & 3.5 & 1 & 2 & \# & 1 & 1 & + & 1 \\
\hline $17 / I$ & 1 & 52.0 & 42.5 & 0.5 & 1 & 4.5 & 0.5 & 2 & \# & 1 & 1 & + & 1 \\
\hline $18 / I$ & 1 & 61.0 & 33.0 & 1.0 & 1 & 5.0 & 1 & 1 & HI & 1 & 1 & + & 1 \\
\hline
\end{tabular}




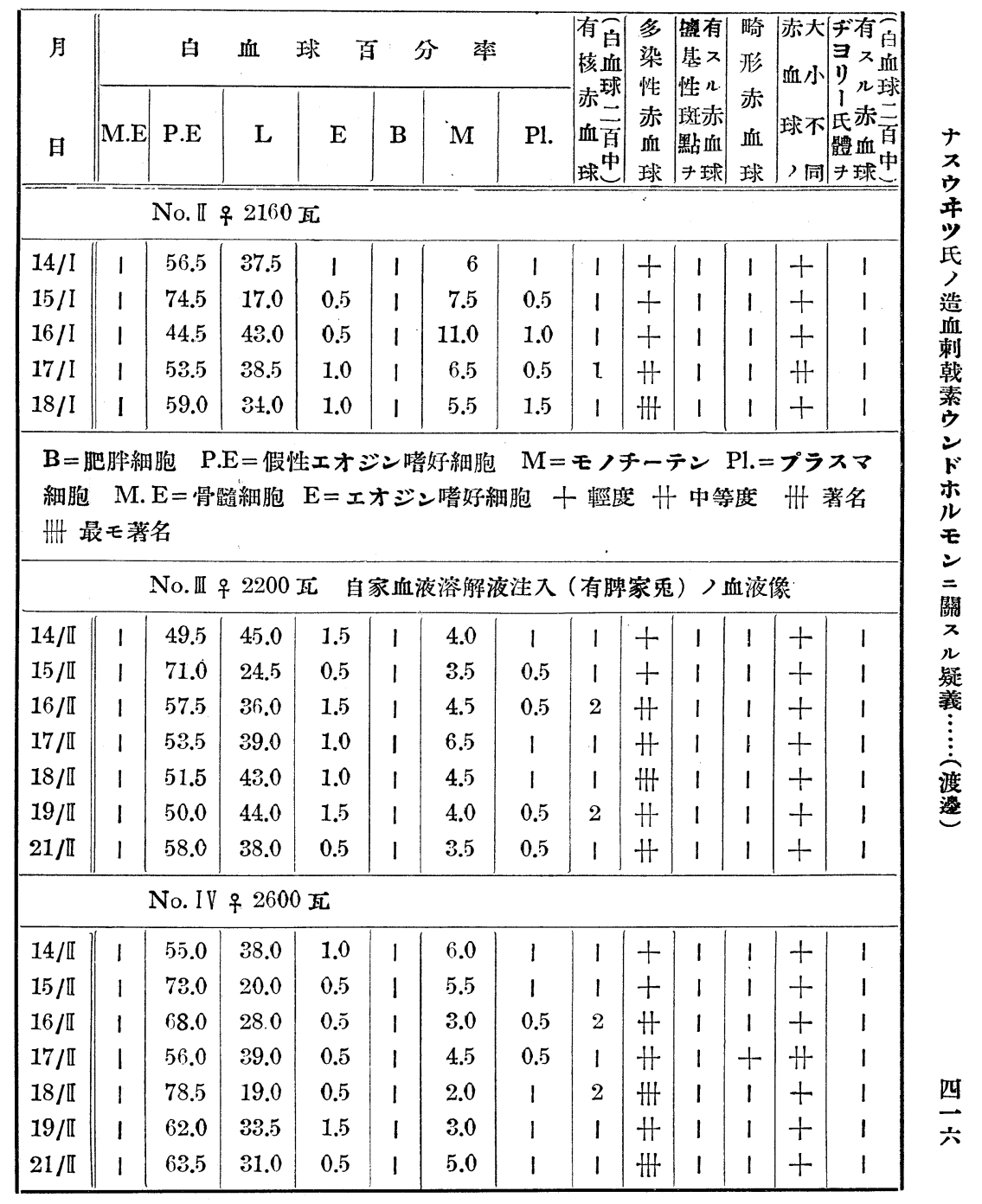




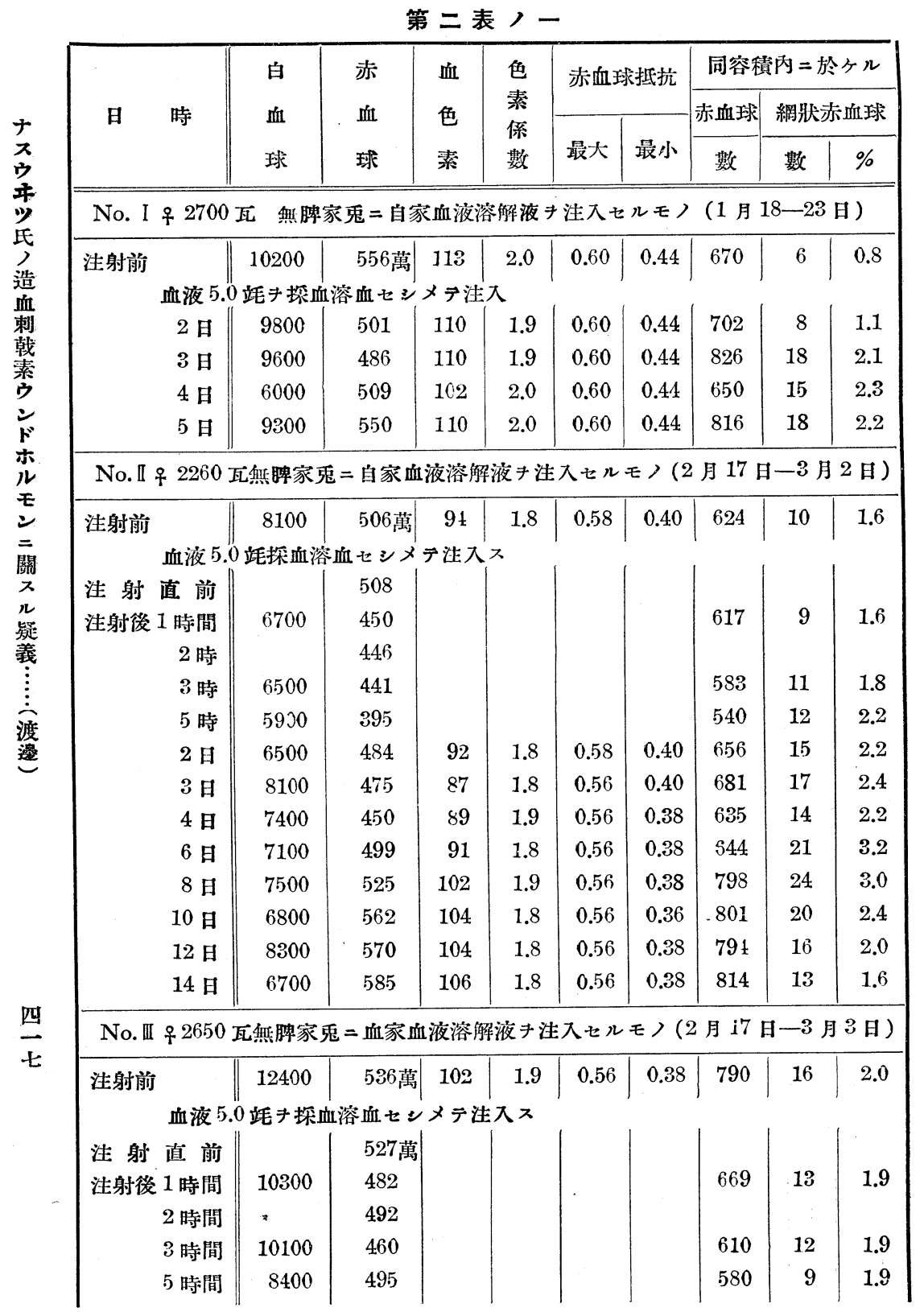




\begin{tabular}{|c|c|c|c|c|c|c|c|c|c|c|}
\hline \multirow{3}{*}{ 日 } & \multirow{3}{*}{ 時 } & \multirow{3}{*}{$\begin{array}{l}\text { 白 } \\
\text { 血 } \\
\text { 球 }\end{array}$} & \multirow{3}{*}{$\begin{array}{l}\text { 赤 } \\
\text { 血 } \\
\text { 球 }\end{array}$} & \multirow{3}{*}{$\begin{array}{l}\text { 血 } \\
\text { 色 } \\
\text { 素 }\end{array}$} & \multirow{3}{*}{$\begin{array}{l}\text { 色 } \\
\text { 素 } \\
\text { 你 } \\
\text { 數 }\end{array}$} & \multicolumn{2}{|c|}{ 赤血球抵抗 } & \multicolumn{3}{|c|}{ 同容積內 =於ヶル } \\
\hline & & & & & & & & \multicolumn{3}{|c|}{ 赤血球 數網狀亦血球 } \\
\hline & & & & & & 最大 & 最小 & 數 & 數 & $\%$ \\
\hline & 2 日 & 9700 & 486 & 92 & 1.8 & 0.56 & 0.36 & 839 & 19 & 2.2 \\
\hline & 3 日 & 7500 & 466 & 94 & 2.0 & 0.54 & 0.36 & 672 & 11 & 1.6 \\
\hline & 4 日 & 8900 & 504 & 95 & 1.7 & 0.54 & 0.36 & 658 & 25 & 3.7 \\
\hline & 6 日 & 8300 & 521 & 98 & 1.7 & 0.56 & 0.36 & 739 & 31 & 4.1 \\
\hline & 8 日 & 8700 & 562 & 100 & 1.7 & 0.56 & 0.38 & 761 & 23 & 3.1 \\
\hline & 10 日 & 6900 & 577 & 103 & 1.8 & 0.56 & 0.36 & 768 & 21 & 2.7 \\
\hline & 12 日 & 7500 & 583 & 105 & 1.8 & 0.56 & 0.38 & 807 & 17 & 2.0 \\
\hline & 14 日 & 6300 & 603 & 105 & 1.7 & 0.58 & 0.38 & 814 & 14 & 1.7 \\
\hline
\end{tabular}

第二表ノ二

No. I \& 2700 瓦無脾家鬼二自家血液溶解液キ注入七几血液像

\begin{tabular}{|c|c|c|c|c|c|c|c|c|c|c|c|c|c|}
\hline \multirow{2}{*}{$\begin{array}{l}\text { 月 } \\
\text { 日 }\end{array}$} & \multicolumn{2}{|r|}{ 白 } & \multicolumn{2}{|c|}{ 血 球 } & 百 & \multicolumn{2}{|c|}{ 杽 } & \multirow{2}{*}{$\begin{array}{l}\text { 有香 } \\
\text { 刻血 } \\
\text { 赤球 } \\
\text { 血百 } \\
\text { 球中 }\end{array}$} & \multirow{2}{*}{$\begin{array}{l}\text { 多 } \\
\text { 染 } \\
\text { 性 } \\
\text { 赤 } \\
\text { 血 } \\
\text { 球 }\end{array}$} & \multirow{2}{*}{ 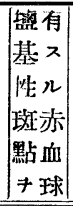 } & \multirow{2}{*}{$\begin{array}{l}\text { 畸 } \\
\text { 形 } \\
\text { 赤 } \\
\text { 血 } \\
\text { 球 }\end{array}$} & \multirow{2}{*}{$\begin{array}{l}\text { 赤 } \\
\text { 血 } \\
\text { 球 } \\
\text { 大 } \\
\text { 小 } \\
\text { 不 } \\
\text { 闹 }\end{array}$} & \multirow{2}{*}{ 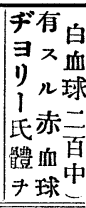 } \\
\hline & M.E & P.E & $\mathbf{L}$ & $\mathrm{E}$ & B & M & Pl & & & & & & \\
\hline $18 / I$ & 1 & 47.5 & 46.0 & 3.5 & 1 & 3.0 & 1 & 1 & $t$ & 1 & 1 & + & 1 \\
\hline $19 / I$ & 1 & 43.0 & 49.5 & 0.5 & 1 & 6.5 & 0.5 & 1 & + & 1 & 1 & + & 1 \\
\hline $20 / I$ & 1 & 37.5 & 56.0 & 1.0 & 1 & 5.5 & 1 & 1 & + & 1 & 1 & + & 1 \\
\hline $21 / I$ & I & 43.5 & 49.0 & 1.5 & 1 & 6.0 & 1 & 1 & + & 1 & 1 & t & 1 \\
\hline $22 / I$ & 1 & 51.5 & 41.0 & 0.5 & 1 & 6.5 & 0.5 & 1 & + & 1 & 1 & + & 1 \\
\hline $23 / I$ & 1 & 48.0 & 46.0 & 0.5 & 1 & 5.0 & 0.5 & 1 & + & 1 & 1 & + & 1 \\
\hline \multicolumn{14}{|c|}{ No.II \& 2250 瓦 } \\
\hline $17 / \pi$ & 1 & 60.0 & 37.0 & 0.5 & 1 & 2.0 & 1 & 1 & + & 1 & 1 & + & 1 \\
\hline $18 / \mathbb{I I}$ & 1 & 60.5 & 36.0 & 0.5 & 1 & 2.5 & 1 & 1 & + & 1 & 1 & + & 1 \\
\hline $19 / \mathbb{I}$ & 1 & 39.5 & 55.5 & 3.0 & 1 & 2.0 & 1 & 1 & + & 1 & 1 & + & 1 \\
\hline $20 /$ II & 1 & 66.0 & 30.0 & 0.5 & 1 & 3.5 & 1 & 1 & + & 1 & 1 & + & 1 \\
\hline $22 / \mathbb{I}$ & 1 & 51.0 & 43.0 & 1 & 1 & 5.5 & 0.5 & 1 & H & 1 & 1 & + & 1 \\
\hline $24 /$ II & 1 & 58.0 & 36.5 & 1 & 1 & 4.5 & 1.0 & 1 & H & 1 & 1 & + & 1 \\
\hline $26 / \mathbb{I}$ & 1 & 59.0 & 36.0 & 1.0 & 1 & 3.0 & 1.0 & 1 & $H$ & 1 & 1 & + & 1 \\
\hline
\end{tabular}




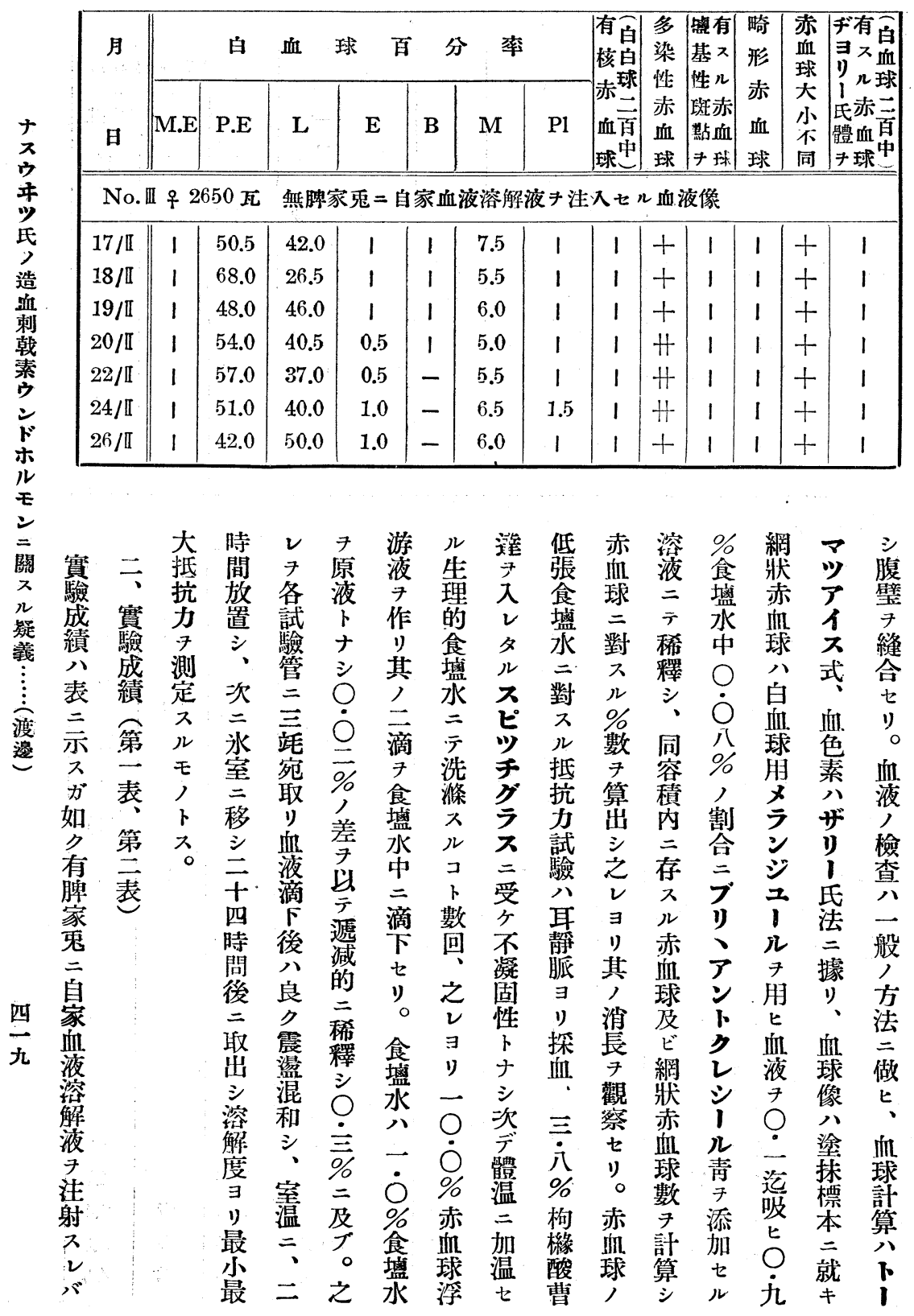


第三表 ノ一

\begin{tabular}{|c|c|c|c|c|c|c|c|c|c|c|}
\hline \multirow{3}{*}{ 日 } & \multirow{3}{*}{ 時 } & \multirow{3}{*}{$\begin{array}{l}\text { 白 } \\
\text { 血 } \\
\text { 球 }\end{array}$} & \multirow{3}{*}{$\begin{array}{l}\text { 赤 } \\
\text { 血 } \\
\text { 球 }\end{array}$} & \multirow{3}{*}{$\begin{array}{l}\text { 血 } \\
\text { 色 } \\
\text { 素 }\end{array}$} & \multirow{3}{*}{$\begin{array}{l}\text { 色 } \\
\text { 素 } \\
\text { 㛊 } \\
\text { 數 }\end{array}$} & \multirow{2}{*}{\multicolumn{2}{|c|}{ 赤血球抵抗 }} & \multicolumn{3}{|c|}{ 同容積内 = 於々ル } \\
\hline & & & & & & & & \multirow{2}{*}{$\frac{\text { 赤血球 }}{\text { 數 }}$} & \multicolumn{2}{|c|}{ 網狀赤血球 } \\
\hline & & & & & & 最大 & 最小 & & 數 & $\%$ \\
\hline \multicolumn{11}{|c|}{ No. I \& 2300 瓦 有脾動物=同種血液溶解液き注入七ルモノ(12月29日-1月4日) } \\
\hline 注射前 & & 8000 & 551 & 104 & 1.9 & 0.60 & 0.42 & 825 & 10 & 1.2 \\
\hline \multicolumn{11}{|c|}{ 同種家鬼ノ血液 5.0 站き溶血セシメテ注入ス } \\
\hline & 2 日 & 14800 & 627 & 110 & 1.7 & 0.62 & 0.48 & 796 & 17 & 2.1 \\
\hline & 3 日 & 10100 & 500 & 109 & 2.8 & 0.62 & 0.48 & 803 & 19 & 2.3 \\
\hline & 5 日 & 9600 & 592 & 108 & 1.8 & 0.62 & 0.50 & 552 & 5 & 0.9 \\
\hline & 6 日 & 5600 & 497 & 101 & 2.0 & 0.62 & 0.44 & 764 & 8 & 1.0 \\
\hline & 7 日 & 6000 & 524 & 103 & 1.9 & 0.60 & 0.42 & 807 & 9 & 1.1 \\
\hline \multicolumn{11}{|c|}{ No. II 守 2600 瓦 } \\
\hline 注射前 & & 10300 & 508 & 89 & 1.8 & 0.60 & 0.42 & 601 & 12 & 1.9 \\
\hline \multicolumn{11}{|c|}{ 同種家鬼ノ血液 5.0 靖 } \\
\hline & 2 日 & 14200 & 495 & 93 & 1.8 & 0.60 & 0.52 & 799 & 8 & 1.0 \\
\hline & 3 日 & 16900 & 537 & 97 & 1.8 & 0.62 & 0.50 & 734 & 12 & 1.6 \\
\hline & 4 日 & 10700 & 471 & 89 & 1.9 & 0.62 & 0.44 & 634 & 38 & 5.9 \\
\hline & 5 日 & 8200 & 486 & 88 & 1.8 & 0.60 & 0.40 & 541 & 42 & 7.7 \\
\hline & 7 日 & 6700 & 543 & 96 & 1.9 & 0.60 & 0.40 & 715 & 33 & 4.4 \\
\hline \multicolumn{11}{|c|}{ No. II 2400 瓦 有脾家鬼二同種血液溶解液キ注入セルモ) (2月18日一2月 26 日 $)$} \\
\hline 注射前 & & 6700 & 524萬 & 101 & 1.9 & 0.60 & 0.42 & 783 & 9 & 1.1 \\
\hline \multicolumn{11}{|c|}{ 同種家鬼血液 5.0 キ溶解セシメテ注入ス } \\
\hline 注射後 1 & 1 時間 & 15300 & 678 & & & & & 831 & 11 & 1.3 \\
\hline & 2 時間 & 19400 & 696 & & & & & & & \\
\hline & 3 時間 & 17200 & 670 & & & & & & & \\
\hline & 4 時間 & 14600 & 641 & & & & & & & \\
\hline & 6 時間 & 10800 & 613 & & & & & & & \\
\hline & 2 日 & 9700 & 577 & 104 & 1.9 & 0.62 & 0.46 & 802 & 13 & 1.6 \\
\hline & 3 日 & 8200 & 469 & 97 & 2.0 & 0.62 & 0.44 & 784 & 10 & 1.2 \\
\hline & 4 日 & 7500 & 516 & 95 & 1.8 & 0.60 & 0.44 & 793 & 14 & 1.7 \\
\hline & 5 日 & 5800 & 548 & 102 & 1.9 & 0.60 & 0.42 & 782 & 19 & 2.4 \\
\hline & 6 日 & 6900 & 557 & 105 & 1.9 & 0.60 & 0.42 & 813 & 25 & 3.0 \\
\hline & 7 日 & 5200 & 536 & 105 & 1.9 & 0.60 & 0.42 & 829 & 38 & 4.5 \\
\hline
\end{tabular}




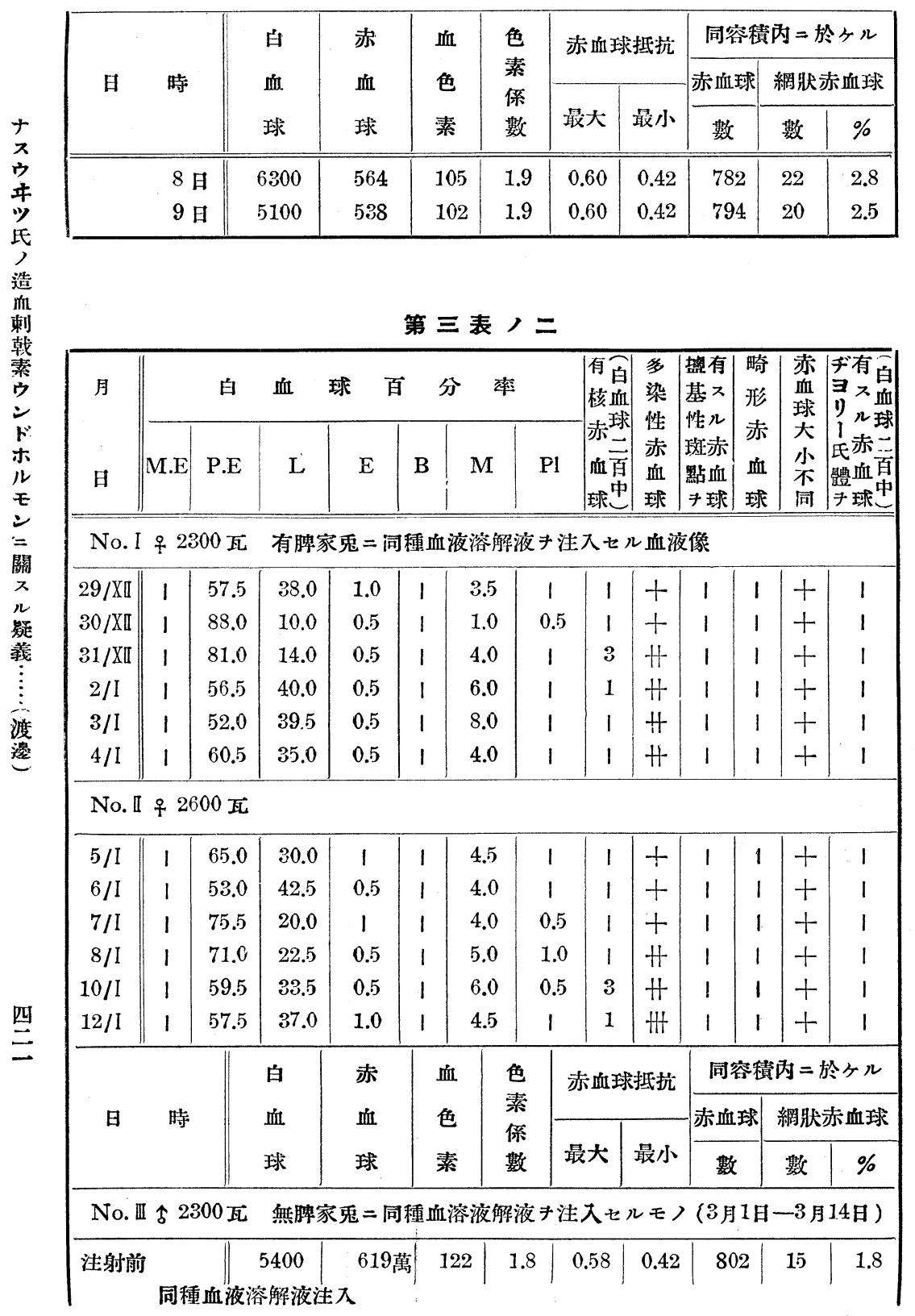




\begin{tabular}{|c|c|c|c|c|c|c|c|c|c|c|}
\hline \multirow{3}{*}{ 日 } & \multirow{3}{*}{ 時 } & \multirow{3}{*}{$\begin{array}{l}\text { 白 } \\
\text { 血 } \\
\text { 球 }\end{array}$} & \multirow{3}{*}{$\begin{array}{l}\text { 赤 } \\
\text { 血 } \\
\text { 球 }\end{array}$} & \multirow{3}{*}{$\begin{array}{l}\text { 血 } \\
\text { 色 } \\
\text { 素 }\end{array}$} & \multirow{3}{*}{$\begin{array}{l}\text { 色 } \\
\text { 素 } \\
\text { 係 } \\
\text { 數 }\end{array}$} & \multirow{2}{*}{\multicolumn{2}{|c|}{ 赤血球抵抗 }} & \multicolumn{3}{|c|}{ 同容積內 =於ヶル } \\
\hline & & & & & & & & \multirow{2}{*}{$\frac{\text { 赤血球 }}{\text { 數 }}$} & \multicolumn{2}{|c|}{ 網狀亦血梂 } \\
\hline & & & & & & 最大 & 最小 & & 數 & $\%$ \\
\hline 注射往 & 1 時間 & 8500 & 588 & & & & & 781 & 13 & 1.7 \\
\hline & 3 時間 & 7400 & 586 & & & & & & & \\
\hline & 5 時間 & 7800 & .576 & & & & & & & \\
\hline & 2 日 & 8400 & 593 & 112 & 1.8 & 0.60 & 0.48 & 826 & 12 & 1.4 \\
\hline & 3 日 & 7800 & 567 & 120 & 1.9 & 0.60 & 0.48 & 831 & 17 & 2.0 \\
\hline & 4 日 & 8300 & 477 & 106 & 2.2 & 0.60 & 0.48 & 692 & 7 & 1.0 \\
\hline & 5 日 & 6400 & 539 & 120 & 2.2 & 0.60 & 0.46 & 824 & 20 & 2.4 \\
\hline & 6 日 & 6800 & 617 & 120 & 1.9 & 0.58 & 0.44 & 806 & 23 & 2.7 \\
\hline & 7 日 & 7800 & 639 & 113 & 1.7 & 0.60 & 0.44 & 823 & 32 & 8.8 \\
\hline & 8 日 & 6700 & 631 & 101 & 1.6 & 0.58 & 0.42 & 817 & 26 & 8.1 \\
\hline & $10 \mathrm{H}$ & 9700 & 613 & 104 & 1.7 & 0.58 & 0.42 & 805 & 32 & 3.9 \\
\hline
\end{tabular}

第四表ノ一

\begin{tabular}{|c|c|c|c|c|c|c|c|c|c|c|}
\hline \multirow{3}{*}{ 日 } & \multirow{3}{*}{ 時 } & \multirow{3}{*}{$\begin{array}{l}\text { 白 } \\
\text { 血 } \\
\text { 球 }\end{array}$} & \multirow{3}{*}{$\begin{array}{l}\text { 赤 } \\
\text { 血 } \\
\text { 球 }\end{array}$} & \multirow{3}{*}{$\begin{array}{l}\text { 血 } \\
\text { 色 } \\
\text { 素 }\end{array}$} & \multirow{3}{*}{$\begin{array}{l}\text { 色 } \\
\text { 素 } \\
\text { 你 } \\
\text { 数 }\end{array}$} & \multicolumn{2}{|c|}{ 赤血球抵抗 } & \multicolumn{3}{|c|}{ 同容積内 =於タル } \\
\hline & & & & & & \multirow[b]{2}{*}{ 最大 } & \multirow[b]{2}{*}{ 最小 } & \multirow{2}{*}{$\frac{\text { 赤血球 }}{\text { 數 }}$} & \multicolumn{2}{|c|}{ 網狀赤血球 } \\
\hline & & & & & & & & & 數 & $\%$ \\
\hline \multicolumn{11}{|c|}{ No.I 311 瓦 無脾家鬼二同種血液溶解液キ注入セルモ) (12月30日一1月7日) } \\
\hline 注射前 & & 9300 & 535萬 & 108 & 2.0 & 0.52 & 0.40 & 910 & 8 & 0.8 \\
\hline \multicolumn{11}{|c|}{ 同種家兔ノ血液 5.0 站キ溶解セシメテ注入フ } \\
\hline & 2 日 & 10300 & 434 & 89 & 2.0 & 0.58 & 0.40 & 781 & 7 & 0.8 \\
\hline & 4 日 & 10000 & 490 & 95 & 1.9 & 0.60 & 0.40 & 838 & 8 & 0.9 \\
\hline & 5 日 & 7800 & 461 & 90 & 1.9 & 0.58 & 0.38 & 847 & 13 & 1.5 \\
\hline & 7 日 & 7100 & 523 & 104 & 1.9 & 0.58 & 0.40 & 875 & 19 & 2.2 \\
\hline & 9 日 & 6900 & 547 & 109 & 1.9 & 0.56 & 0.40 & 856 & 23 & 2.8 \\
\hline \multicolumn{11}{|c|}{ No. II \& 2450 瓦 } \\
\hline 注射前 & & 11600 & 504 & 101 & 1.9 & 0.56 & 0.38 & 783 & 14 & 1.7 \\
\hline \multicolumn{11}{|c|}{ 同種家鬼血液 5.0 竜キ溶解セシメデ注入ス } \\
\hline & 2 日 & 5800 & 501 & 100 & 1.9 & 0.60 & 0.44 & 727 & 10 & 1.3 \\
\hline & 3 日 & 9200 & 476 & 94 & 1.9 & 0.60 & 0.44 & 700 & 7 & 1.0 \\
\hline & 5 日 & 7600 & 509 & 101 & 1.9 & 0.58 & 0.42 & 736 & 12 & 1.6 \\
\hline
\end{tabular}




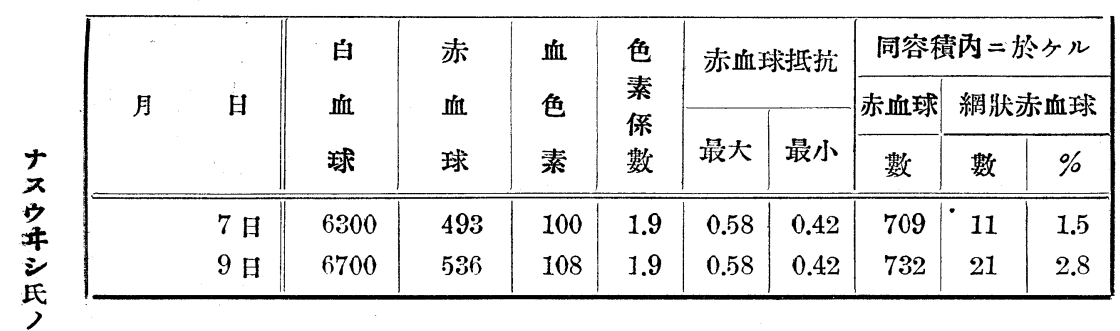

第四表ノニ

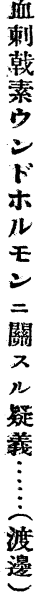

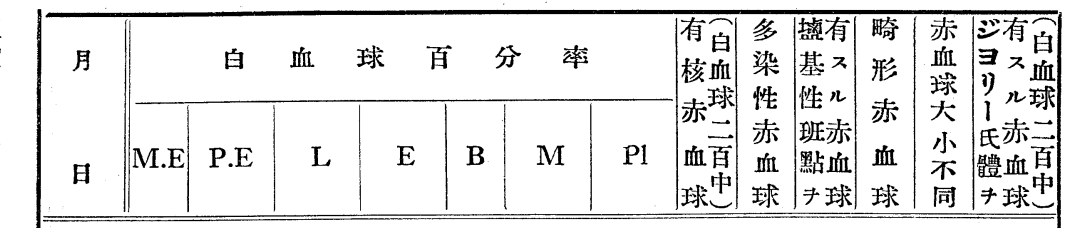

No. I 古 3100 瓦 無脾家鬼二同種血液溶解液キ注入七儿血球像

\begin{tabular}{|c|c|c|c|c|c|c|c|c|c|c|c|c|c|}
\hline $30 / 12$ & 1 & 56.5 & 38.0 & 1.0 & 1 & 4.5 & 1 & 1 & + & 1 & 1 & + & 1 \\
$31 / 12$ & 1 & 57.5 & 40.0 & 1.0 & 1 & 1.5 & 1 & 1 & + & 1 & 1 & + & 1 \\
$2 / 1$ & 1 & 52.5 & 43.0 & 1.5 & 1 & 3.0 & 1 & 1 & + & 1 & 1 & + & 1 \\
$3 / 1$ & 1 & 54.5 & 43.0 & 0.5 & 1 & 2.0 & 1 & 1 & + & 1 & 1 & + & 1 \\
$5 / 1$ & 1 & 60.0 & 35.5 & 0.5 & 1 & 3.0 & 1.0 & 1 & +1 & 1 & 1 & + & 1 \\
$7 / 1$ & 1 & 57.0 & 36.5 & 0.5 & 1 & 5.0 & 1 & 1 & +1 & 1 & 1 & 1 \\
\hline
\end{tabular}

No. II \& 2450 瓦

\begin{tabular}{|c|c|c|c|c|c|c|c|c|c|c|c|c|c|}
\hline $6 / 1$ & 1 & 54.0 & 40.0 & 0.5 & 1 & 5.0 & 1 & 1 & + & 1 & 1 & + & - \\
\hline $7 / 1$ & 1 & 60.5 & 35.0 & 0.5 & 1 & 4.0 & 1 & 1 & + & 1 & 1 & + & - \\
\hline $8 / 1$ & 1 & 61.5 & 34.0 & 0.5 & 1 & 3.5 & 0.5 & 1 & H & 1 & 1 & + & - \\
\hline $10 / 1$ & 1 & 57.0 & 36.5 & 1.0 & 1 & 4.5 & 1.0 & 1 & $H$ & 1 & 1 & + & - \\
\hline $12 / 1$ & 1 & 57.0 & 38.5 & 1 & 1 & 4.5 & 0.5 & 1 & $H$ & 1 & 1 & + & - \\
\hline $14 / 1$ & 1 & 53.0 & 41.0 & 0.5 & 1 & 5.0 & 0.5 & 1 & $H$ & 1 & 1 & + & - \\
\hline \multicolumn{14}{|c|}{ No. III \& 2400 瓦 有脾家鬼 = 同種血液溶解液头注入セ儿血液像 } \\
\hline $18 / 2$ & 1 & 54.5 & 39.0 & 0.5 & 1 & 5.5 & 0.5 & 1 & + & 1 & 1 & + & 1 \\
\hline $19 / 2$ & 1 & 69.5 & 27.0 & 0.5 & 1 & 2.5 & 0.5 & 1 & + & 1 & 1 & + & 1 \\
\hline $20 / 2$ & 1 & 72.0 & 25.0 & 1 & 1 & 3.0 & 1 & 1 & + & 1 & 1 & + & 1 \\
\hline $21 / 2$ & 1 & 67.5 & 29.0 & 0.5 & 1 & 3.0 & 1 & 1 & H & 1 & 1 & + & 1 \\
\hline $22 / 2$ & 1 & 58.0 & 36.0 & 1 & 1 & 5.0 & 0.5 & 1 & H & 1 & + & + & 1 \\
\hline $24 / 2$ & 1 & 56.5 & 37.0 & 1.5 & 1 & 4.5 & 0.5 & 1 & $H$ & 1 & 1 & + & 1 \\
\hline $25 / 2$ & 1 & 60.0 & 32.0 & 1 & 1 & 7.5 & 0.5 & 1 & $H$ & 1 & 1 & + & 1 \\
\hline
\end{tabular}




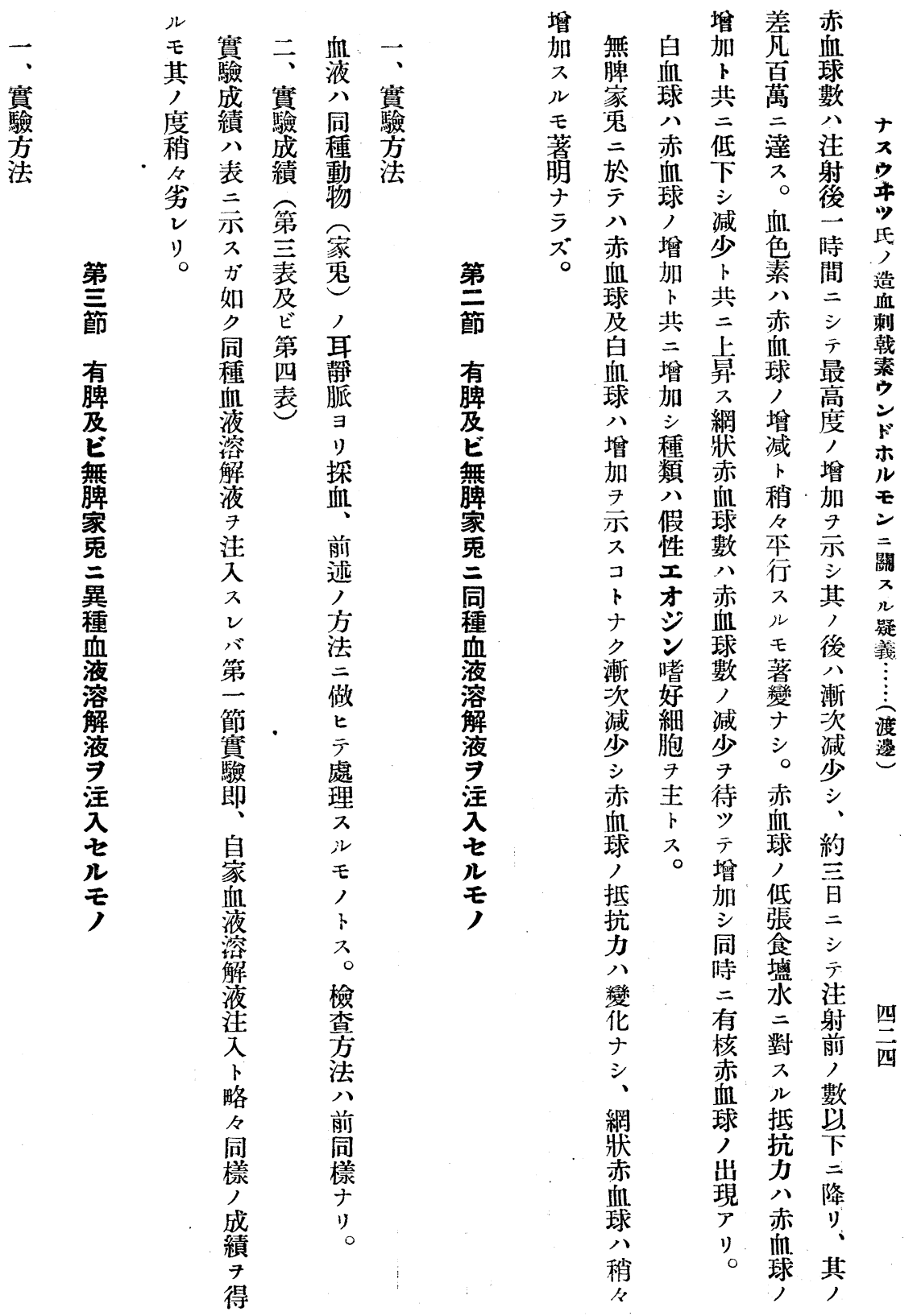




\begin{tabular}{|c|c|c|c|c|c|c|c|c|c|c|}
\hline \multirow{3}{*}{ 日 } & \multirow{3}{*}{ 時 } & \multirow{3}{*}{$\begin{array}{l}\text { 白 } \\
\text { 血 } \\
\text { 球 }\end{array}$} & \multirow{3}{*}{$\begin{array}{l}\text { 赤 } \\
\text { 血 } \\
\text { 球 }\end{array}$} & \multirow{3}{*}{$\begin{array}{l}\text { 血 } \\
\text { 色 } \\
\text { 素 }\end{array}$} & \multirow{3}{*}{$\begin{array}{l}\text { 色 } \\
\text { 素 } \\
\text { 你 } \\
\text { 數 }\end{array}$} & \multicolumn{2}{|c|}{ 赤血球抵抗 } & \multicolumn{3}{|c|}{ 同容積內 =於ヶル } \\
\hline & & & & & & & & \multirow{2}{*}{$\left|\frac{\mid}{\text { 赤血球 }}\right|$} & \multicolumn{2}{|c|}{ 網狀赤血球 } \\
\hline & & & & & & 最大 & 最小 & & 數 & $\%$ \\
\hline \multicolumn{11}{|c|}{ No. I \& 2050 瓦 有脾家鬼二異種血液溶解液キ注入セルモノ(1月31日一 2 月 6 日) } \\
\hline 注射前 & & 9200 & 537萬 & 107 & 1.9 & 0.58 & 0.44 & 882 & 13 & 1.4 \\
\hline \multicolumn{11}{|c|}{ 山羊ノ血液 5.0 站テ溶血セシメテ注入ス } \\
\hline & 2 日 & 13500 & 519 & 102 & 1.9 & 0.62 & 0.50 & 666 & 5 & 0.7 \\
\hline & 3 日 & 16900 & 498 & 98 & 2.0 & 0.52 & 0.46 & 784 & 13 & 1.6 \\
\hline & 4 日 & 14700 & $\dot{455}$ & 94 & 2.0 & 0.62 & 0.44 & 769 & 7 & 0.9 \\
\hline & 5 日 & 10800 & 481 & 98 & 2.0 & 0.60 & 0.40 & 759 & 18 & 2.3 \\
\hline & 7 日 & 10300 & 513 & 100 & 1.9 & 0.58 & 0.40 & 762 & 37 & 4.8 \\
\hline \multicolumn{11}{|c|}{ No. II \& 2450 瓦 } \\
\hline 注射前 & & 8800 & 608 & 106 & 1.7 & 0.62 & 0.44 & 732 & 12 & 1.6 \\
\hline \multicolumn{11}{|c|}{ 山羊ノ血液 5.0 犝き溶血セシメテ注入ス } \\
\hline \multicolumn{2}{|c|}{ 注射後 1 時間 } & 17600 & 614 & & & & & \multirow[b]{4}{*}{699} & \multirow[b]{4}{*}{16} & \multirow[b]{4}{*}{2.3} \\
\hline & 3 時間 & 12400 & 597 & & & & & & & \\
\hline \multicolumn{2}{|r|}{5 時問 } & 10700 & 623 & & & & & & & \\
\hline & 2 日 & 11000 & 572 & 120 & 2.0 & 0.62 & 0.48 & & & \\
\hline & 3 日 & 12800 & 618 & 120 & 2.0 & 0.60 & 0.46 & 799 & 15 & 1.8 \\
\hline & 4 日 & 11200 & 530 & 114 & 2.0 & 0.62 & 0.46 & 784 & 11 & 1.4 \\
\hline & 5 日 & 10700 & 597 & 120 & 2.0 & 0.60 & 0.46 & 796 & 14 & 1.7 \\
\hline \multicolumn{11}{|c|}{ 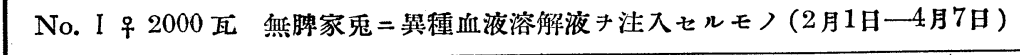 } \\
\hline \multicolumn{2}{|c|}{ 注射前 } & 8600 & 561 & 106 & 1.8 & 0.58 & 0.38 & 807 & 11 & 1.3 \\
\hline \multicolumn{11}{|c|}{ 山羊ノ血液 5.0 站き溶血セシメア注入ス } \\
\hline \multirow[t]{5}{*}{ 注射後 } & 2 日 & 17300 & 529 & 104 & 1.9 & 0.60 & 0.42 & 684 & 9 & 1.3 \\
\hline & 3 日 & 10400 & 465 & 94 & 2.0 & 0.60 & 0.38 & 839 & 23 & 2.7 \\
\hline & 4 日 & 12600 & 520 & 100 & 1.9 & 0.56 & 0.38 & 778 & 19 & 2.4 \\
\hline & 5 日 & 10400 & 537 & 101 & 1.8 & 0.56 & 0.36 & 765 & 18 & 2.3 \\
\hline & 7 日 & 10500 & 564 & 105 & 1.8 & 0.56 & 0.36 & 773 & 17 & 2.1 \\
\hline
\end{tabular}




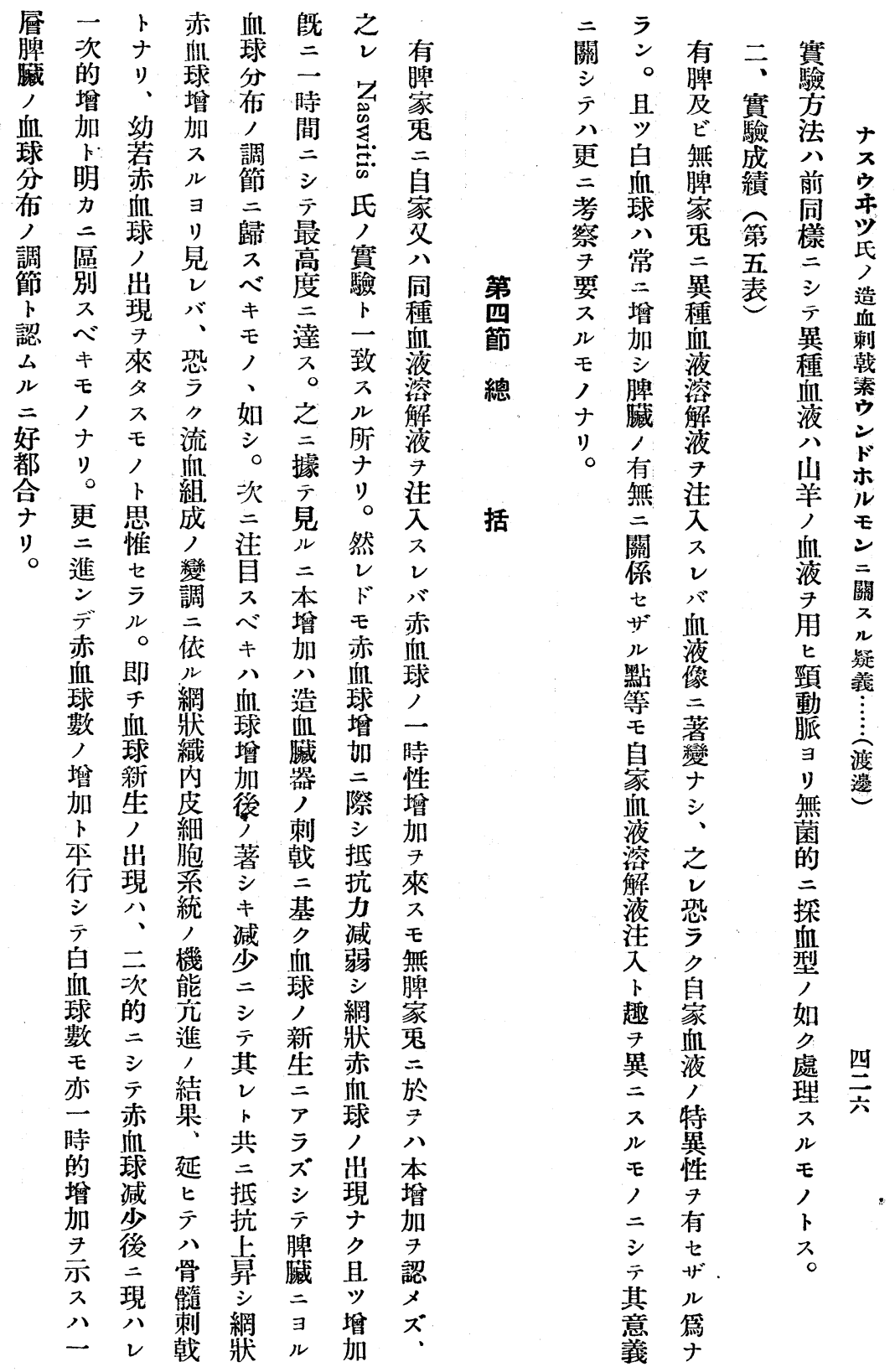




\begin{tabular}{|c|c|c|c|c|c|c|c|c|c|c|}
\hline \multirow{3}{*}{ 日 } & \multirow{3}{*}{ 時 } & \multirow{3}{*}{$\begin{array}{l}\text { 白 } \\
\text { 血 } \\
\text { 球 }\end{array}$} & \multirow{3}{*}{$\begin{array}{l}\text { 赤 } \\
\text { 血 } \\
\text { 球 }\end{array}$} & \multirow{3}{*}{$\begin{array}{l}\text { 血 } \\
\text { 色 } \\
\text { 素 }\end{array}$} & \multirow{3}{*}{$\begin{array}{l}\text { 色 } \\
\text { 素 } \\
\text { 㛊 } \\
\text { 數 }\end{array}$} & \multicolumn{2}{|c|}{ 赤血球抵抗 } & \multicolumn{3}{|c|}{ 同容積内 $=$ 於ヶル } \\
\hline & & & & & & & & \multirow{2}{*}{$\frac{\text { 赤血球 }}{\text { 數 }}$} & \multicolumn{2}{|c|}{ 網狀赤血球 } \\
\hline & & & & & & 最大 & 最小 & & 數 & $\%$ \\
\hline \multicolumn{11}{|c|}{ 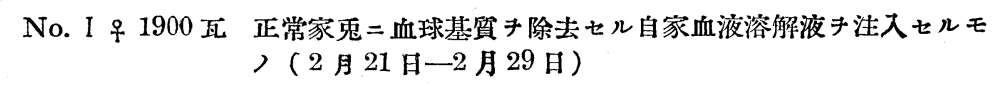 } \\
\hline 注射前 & & 6100 & 515 & 100 & 1.9 & 0.60 & 0.44 & 852 & 13 & 1.8 \\
\hline \multicolumn{11}{|c|}{ 血液 5.0 䇇琛血溶血セシメテ血球基礎質き除去シテ注入ス } \\
\hline 注射後 & 1 時間 & 10900 & 616 & & & & & & & \\
\hline & 2 時間 & & 522 & & & & & & & \\
\hline & 3 時間 & 9800 & 583 & & & & & & & \\
\hline & 4 時間 & 10700 & 579 & & & & & & & \\
\hline & 2 日 & 5900 & 565 & 91 & 1.9 & 0.62 & 0.46 & 723 & 14 & 1.9 \\
\hline & 3 日 & 4500 & 483 & 89 & 1.8 & 0.62 & 0.46 & 728 & 23 & 3.1 \\
\hline & 5 日 & 6200 & 548 & 109 & 1.9 & 0.62 & 0.44 & 731 & 21 & 2.8 \\
\hline & 7 日 & 6900 & 561 & 110 & 1.9 & 0.60 & 0.44 & 719 & 17 & 2.3 \\
\hline & 9 日 & 5700 & 534 & 105 & 1.9 & 0.60 & 0.42 & 726 & 13 & 1.7 \\
\hline \multicolumn{11}{|c|}{ 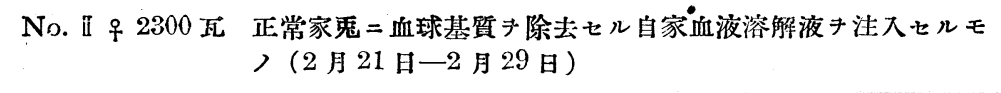 } \\
\hline 注射前 & & 6600 & 538萬 & 100 & 1.8 & 0.60 & 0.44 & 864 & 11 & 1.2 \\
\hline \multicolumn{11}{|c|}{ 血液 5.0 踽于探血溶血セシメテ血球基質き除去シ注入ス } \\
\hline 注射後 & 1 時間 & 14900 & 606 & & & & & & & \\
\hline & 2 時間 & & 545 & & & & & & & \\
\hline & 3 時間 & & 591 & & & & & & & \\
\hline & 4 時間 & & 600 & & & & & & & \\
\hline & 6 時間 & 14600 & 543 & & & & & & & \\
\hline & 2 日 & 6200 & 563 & 99 & 1.9 & 0.62 & 0.48 & 709 & 10 & 1.4 \\
\hline & 3 日 & 4400 & 475 & 94 & 1.9 & 0.62 & 0.46 & 760 & 28 & 3.6 \\
\hline & 5 日 & 7600 & 552 & 109 & 1.9 & 0.60 & 0.44 & 715 & 19 & 2.6 \\
\hline & 7 日 & 6300 & 514 & 108 & 1.9 & 0.60 & 0.44 & 744 & 25 & 3.2 \\
\hline & 9 日 & 8400 & 568 & 110 & 1.9 & 0.60 & 0.44 & 723 & 17 & 2.3 \\
\hline
\end{tabular}




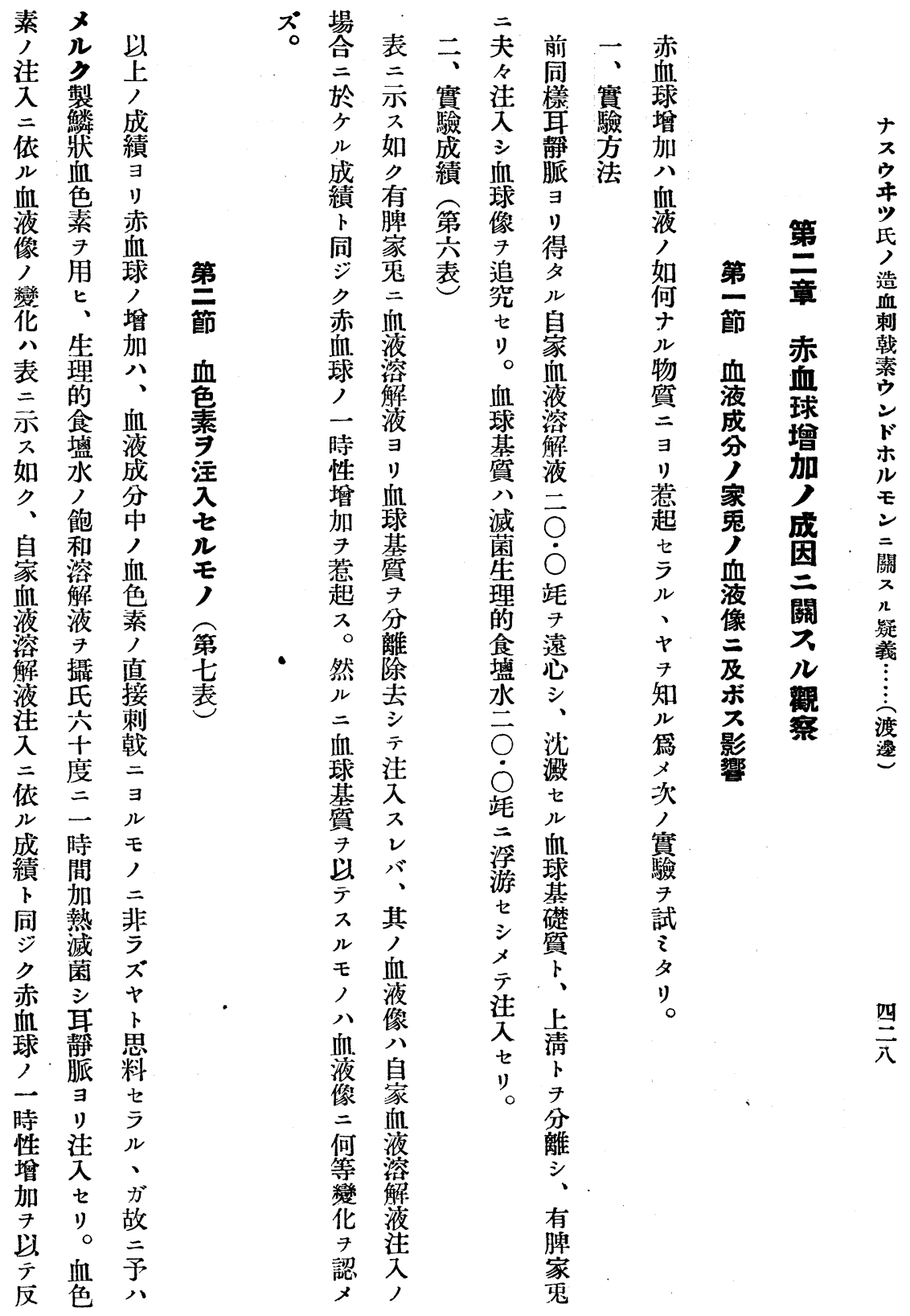


第七表ノ一

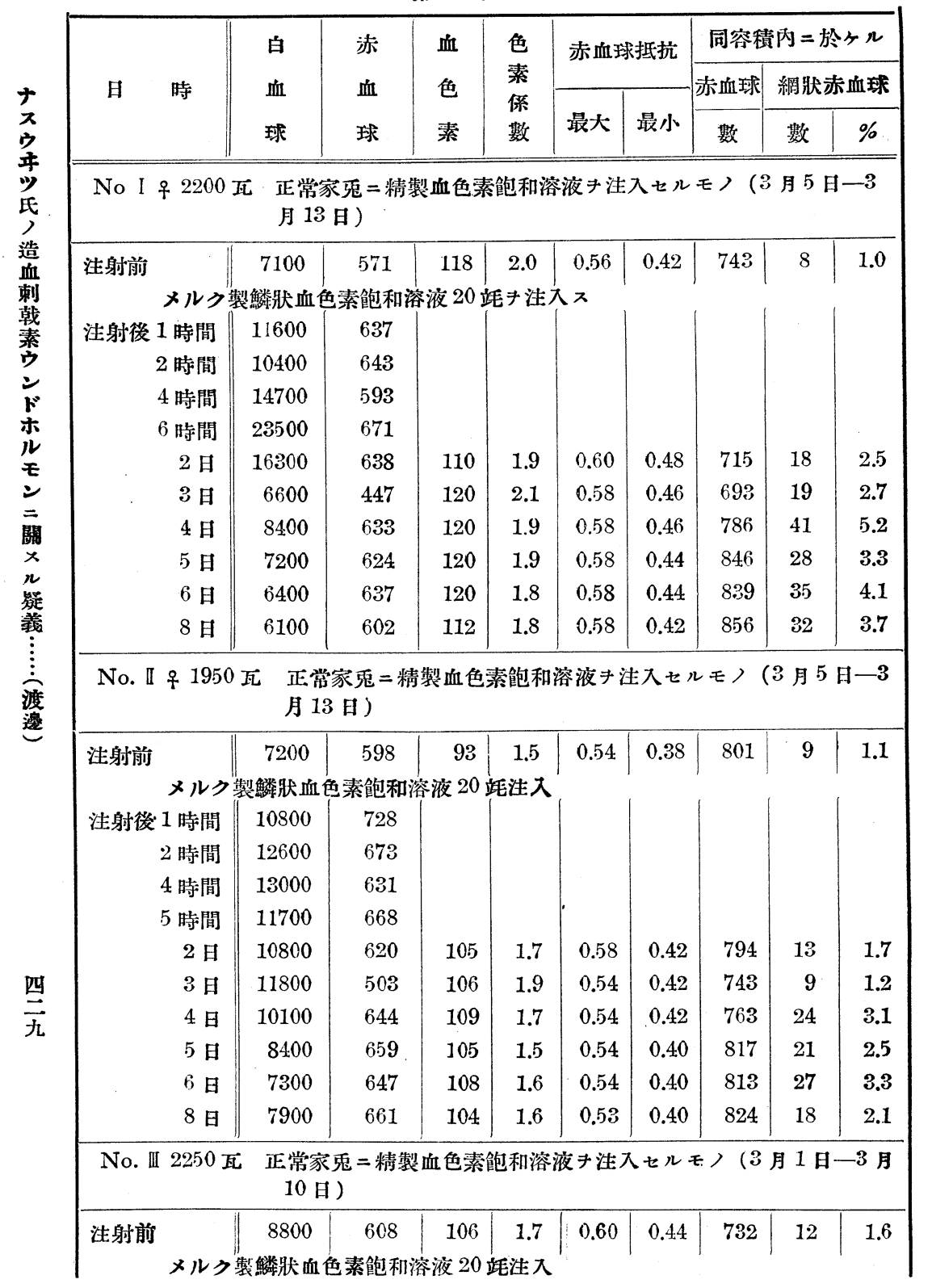




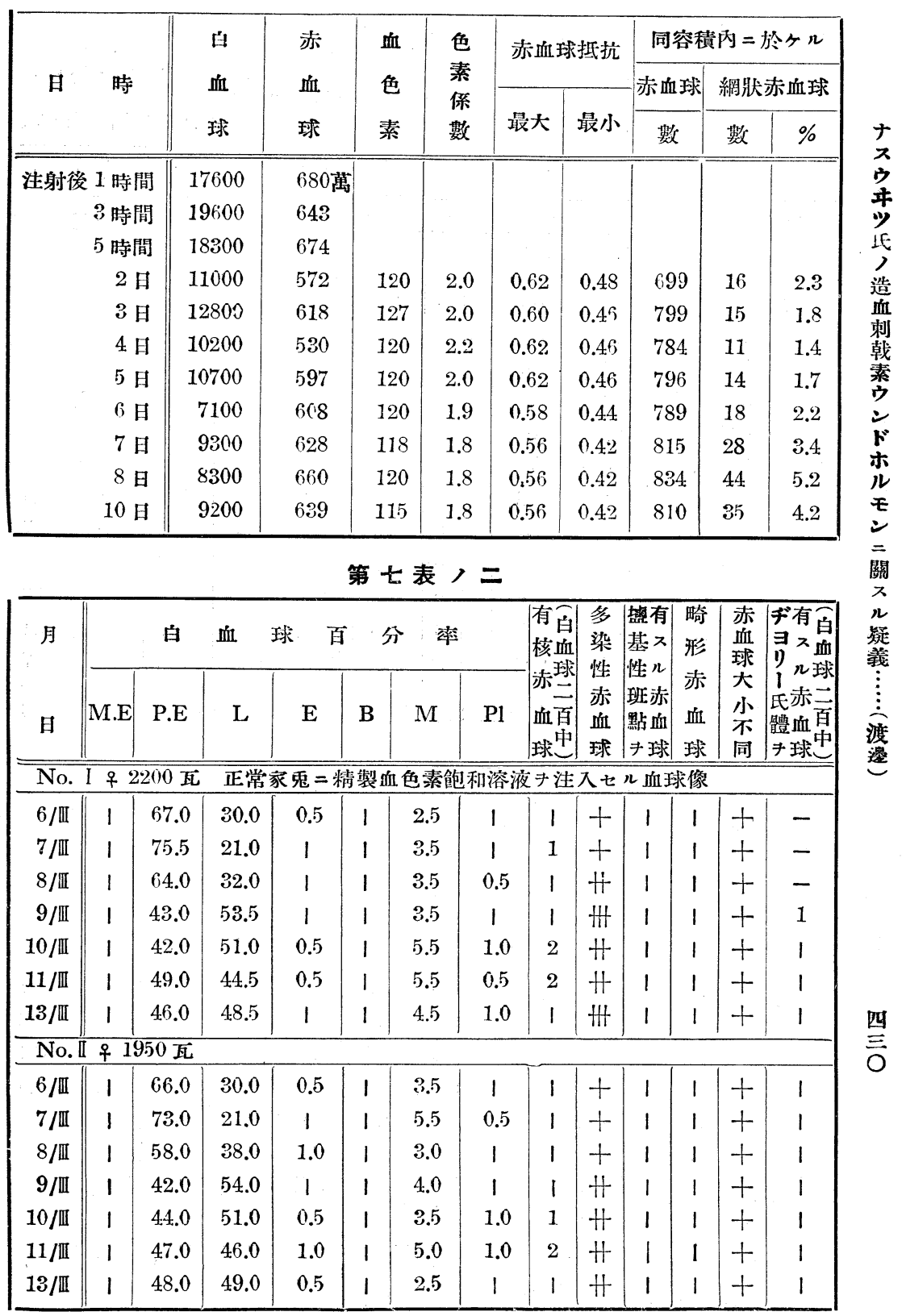




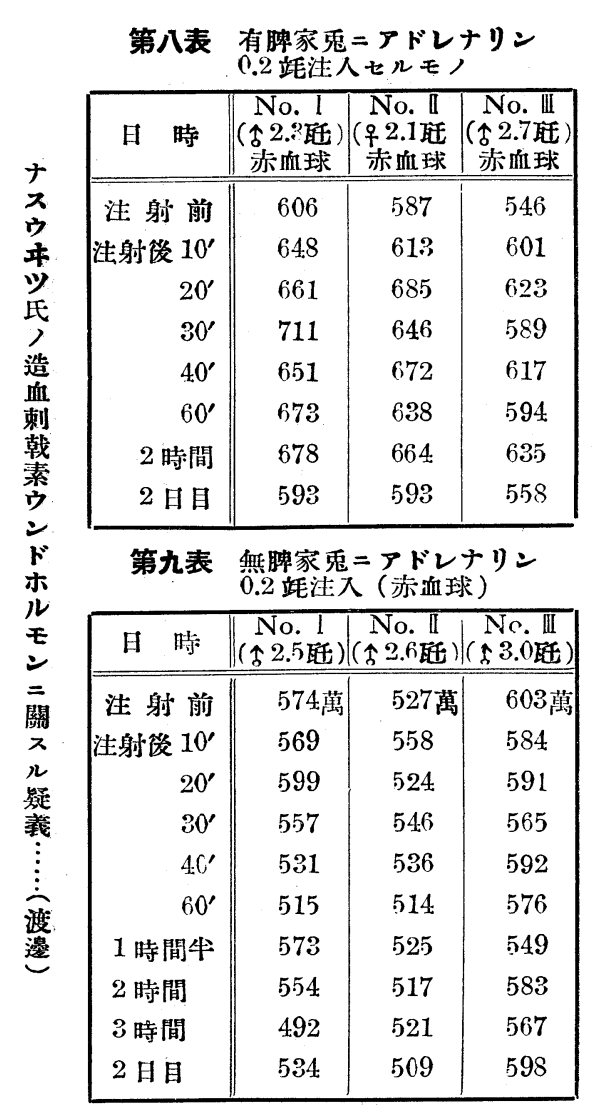

\begin{tabular}{|c|c|c|}
\hline 第十表 & \multicolumn{2}{|c|}{$\begin{array}{l}\text { 聘臟剔山ノ際=於々 } \\
\text { ル赤血球ノ消長 }\end{array}$} \\
\hline & \multicolumn{2}{|c|}{ 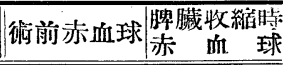 } \\
\hline \multicolumn{3}{|c|}{$(\angle A 20$ 日) } \\
\hline No. I & 542 萬 & 597萬 \\
\hline No. II & 526 & 549 \\
\hline No. II & 513 & 598 \\
\hline \multicolumn{3}{|c|}{ ( ( 月 27 日) } \\
\hline No. I & 501 & 547 \\
\hline No. II & 498 & 577 \\
\hline No. II & 465 & 571 \\
\hline No. IV & 568 & 582 \\
\hline
\end{tabular}

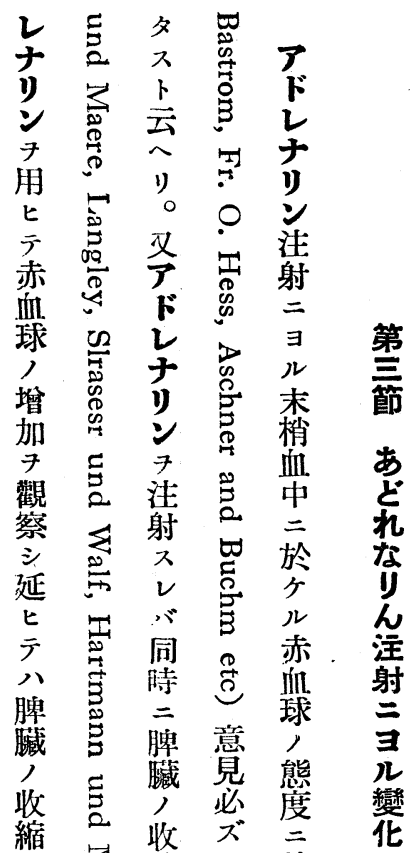

應 


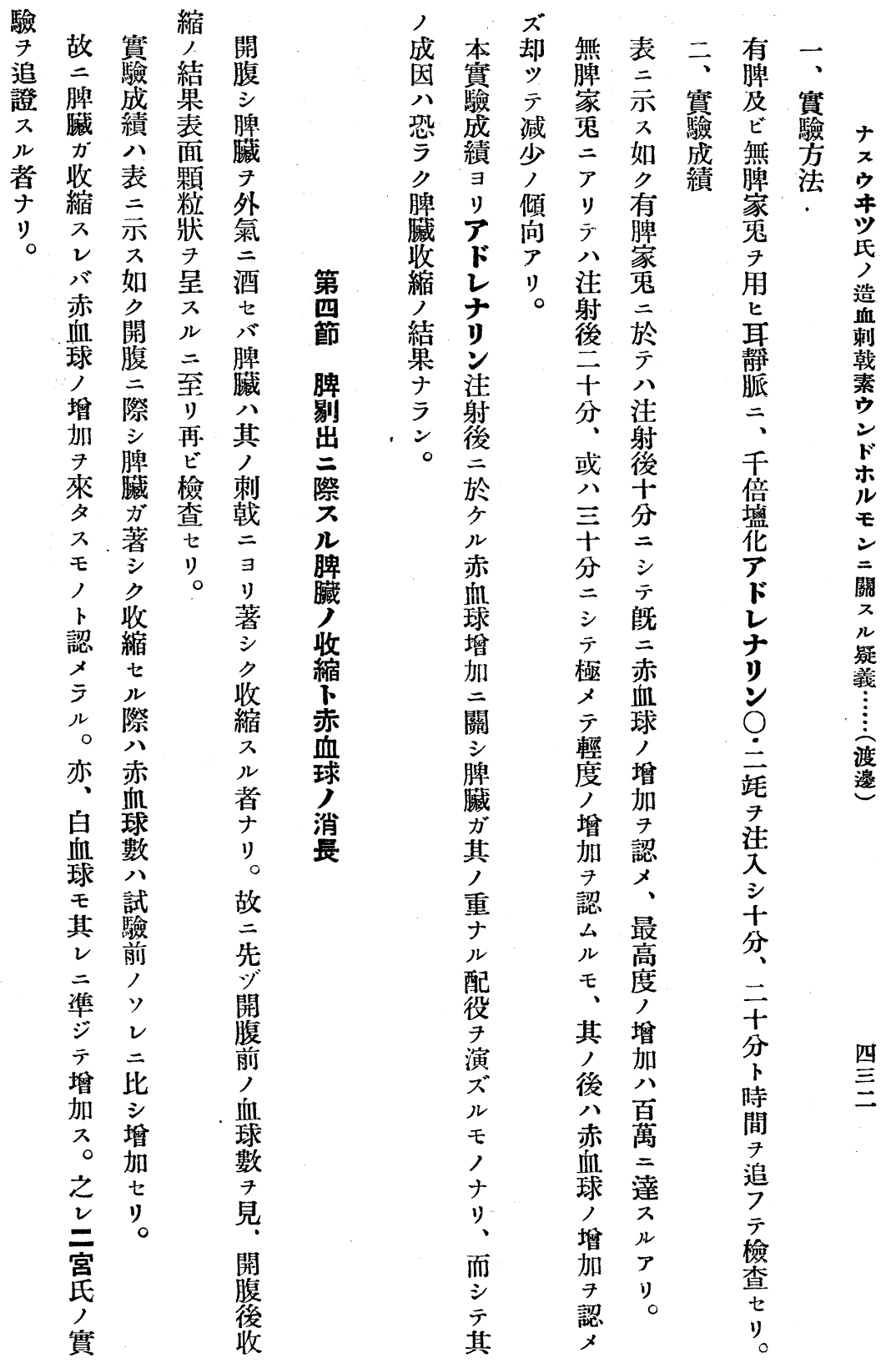




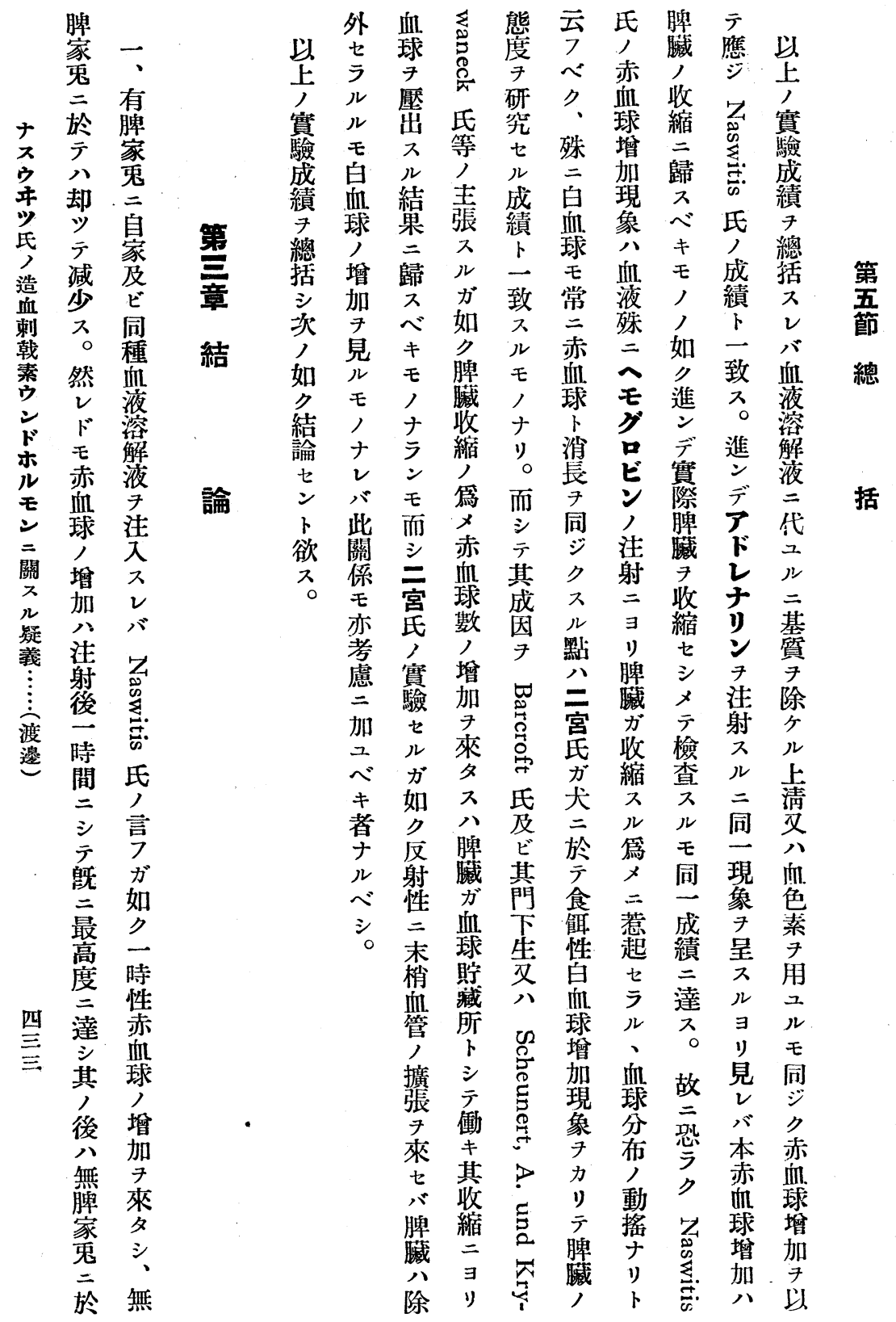




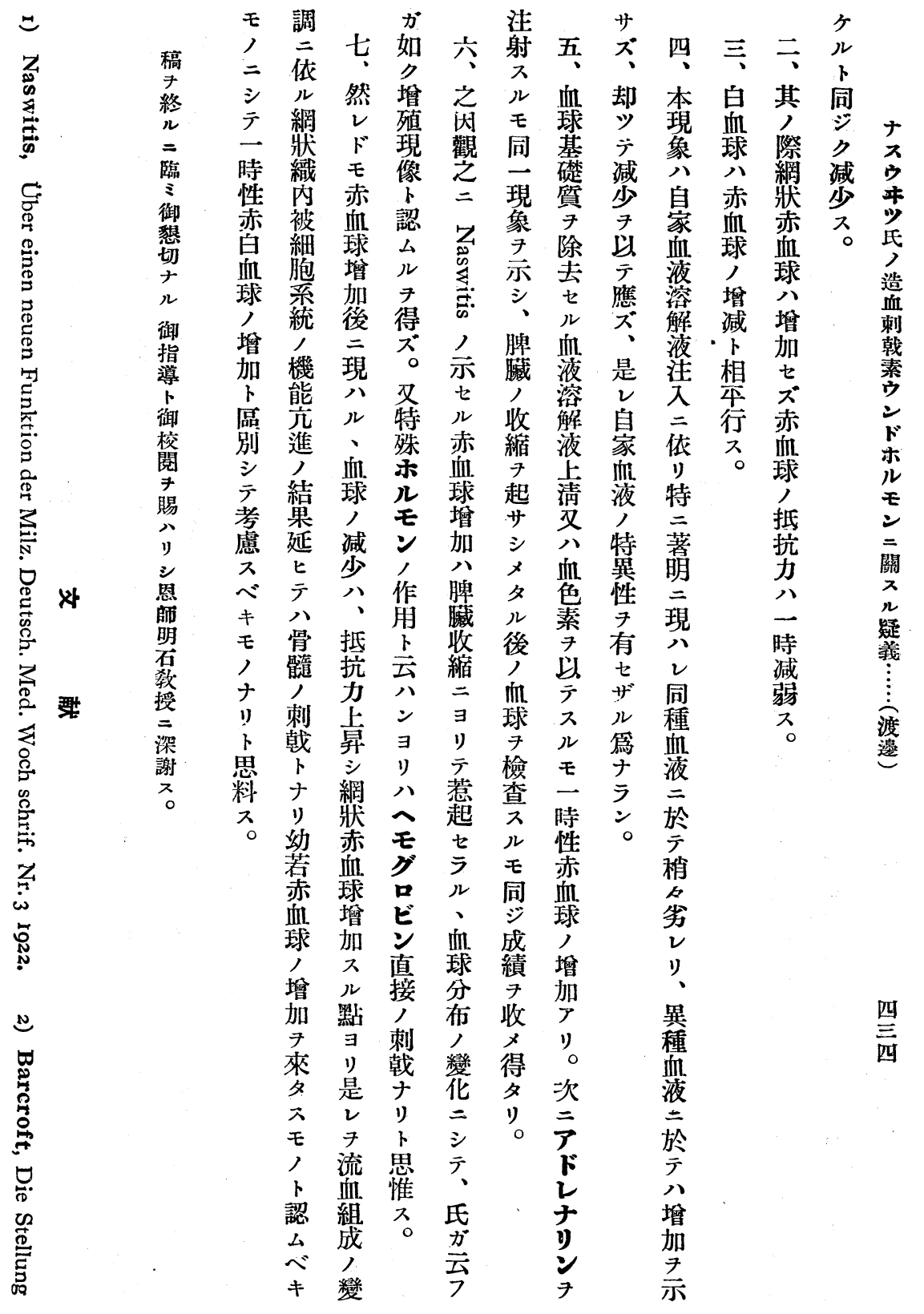




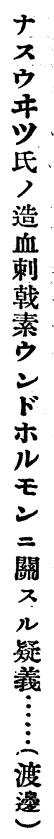

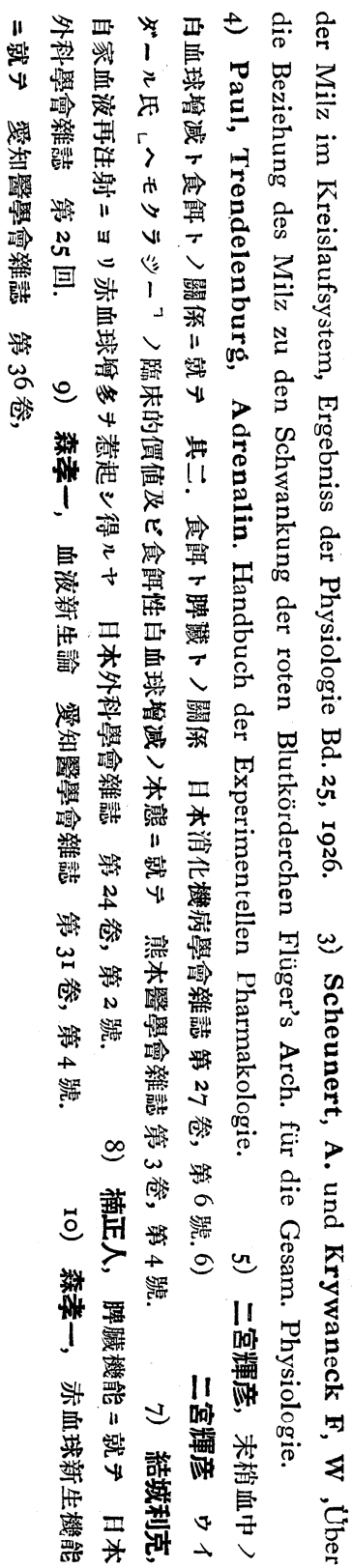


4) Der Einfluss der Ovarialhormone auf künstlich erzeugte Serumanaphylaxie war auch undeutlich. Durch die Kastration und die parenterale Einverleibung von Ovarialsubstanzextrakt wurde die anaphylaktische Shockerscheinung weder abgeschwächt noch gehemmt. Vielmehr schien sie bei den kastrierten Kaninchen etwas hochgradiger aufzutreten, und die Steigerung des K/CaQuotienten im Blutserum nach dem Shockversuch war dabei am auffallendsten.

(Autoreferat)

\title{
Zur Frage der Naswitisschen Wundhormone des Blutes.
}

\author{
Von \\ Dr. F. Watanabe.
}

(Aus der med. Klinik von Prof. M. Akaschi, med.

Akademie zu Kumamoto)

Der Verfasser prüfte den Naswitisschen Versuch über die sogenannten Wundhormone nach. Es war fraglich, ob es sich bei der Zellenvermehrung nach Bluttransfusion um eine Regeneration der Erythrozyten oder um eine Regulation der Blutverteilung handelt. Deshalb habe ich folgende Versuche an normalen und milzlosen Kaninchen angestellt. Diese Kaninchen wurden mit Blutlösung (eigene, von einem anderen Kaninchen oder von einer anderen Tierart) injiziert.

Ich habe dieses Blut defibriniert, sich auflösen lassen, dann auf die Körpertemperatur erwärmt und davon diesem Kaninchen $15 \ldots \ldots \ldots . . .20 \mathrm{ccm}$ intravenös injiziert. Darauf habe ich das Blutbild, die Retikulozytenzahl und die Erythrozytenresistenz gegen hypotonische Kochsalzlösung beobachtet. Ich fand dabei ein Resultat, das gegen die Anschauung von Naswitis spricht.

Bei normalen Kaninchen kam es, wie auch Naswitis angegeben hat, schon eine Stunde nach der Injektion zu beträchtlicher vor- 
übergehender Blutzellenvermehrung. Aber die Retikulozytenzahl war nicht vermehrt, und die Erythrozytenresistenz hatte im Gegenteil abgenommen. Darauf nahmen die Erythrozyten allmählich an Zahl ab, und am 3. Tage trat ein Erythrozytensturz auf. Hierauf steig die Anzahl der Erythrozyten allmählich wieder, und zwar über den normalen Wert hinaus. Auch die Retikulozyten vermehrten sich, und die Erythrozytenresistenz nahm zu.

Bei den milzlosen Tieren wurde keine Blutvermehrung gefunden, sondern es zeigte sich eine allmähliche Abnahme des Blutes. Auch die Vermehrung und die Verminderung der Leukozyten ging nahezu parallel mit jenen Erscheinungen bei den Erythrozyten.

Um das Wesen der Erythrozytenvermehrung festzustellen, injizierte der Verfasser Blut, aus dem das Stroma entfernt worden war, und das Resultat war dasselbe wie oben. Auch nach der Injektion von Hämoglobinlösung(E. Merck. Hämoglobin in Lamellen) und von Adrenalin fand sich Erythrozytenzunahme. Bei starker Kontraktion der Milz während der Laparotomie zeigten sich die Erythrozyten stets vermehrt. Aus seinem Ergebnisse möchte der Verfasser den Schluss ziehen, dass es sich bei der von Naswitis angegebenen Zellenvermehrung nicht, wie er behauptet, um Regeneration der Erythrozyten, sondern um Veränderung der Blutkörperchenverteilung infolge der Milzkontraktion handelt, und dass bei der Wirkung der Bluttransfusion nicht die Einwirkung spezifischer Hormone, der sogenannten "Wundhormone" des Blutes, in Frage kommt, sondern nur die direkte Wirkung des Hämoglobins.

Aber die Erythrozytenabnahme nach anfänglicher Zunahme muss mit der Steigerung der Funktion des Retikuloendothelialsystems zusammenhängen, weil die Zunahme der Retikulozyten und die Steigerung der Erythrozytenresistenz gleichzeitig eintreten, welche Funktionsteigerung weiter einen Reiz auf das Knochenmark ausübt, wodurch es zur Produktion neuer roter Blutkörperchen kommt.

(Autoreferat) 